\title{
POLA PENGAWASAN BAITUL MAAL WAT TAMWIL (BMT) YANG BERBADAN HUKUM KOPERASI
}

\author{
Beny Nurhadi \\ Magister Ilmu Hukum Universitas Diponegoro Semarang \\ beny.nurhadi@gmail.com
}

\begin{abstract}
ABSTRAK
Munculnya keuangan mikro syariah Ini bertujuan untuk memberikan model yang lebih baik dalam menangani isu tingkat bunga tinggi dan lainnya dalam islam. Namun secara teknis operasional masih dihadapkan pada sekian banyak permasalahan perlu segera dipecahkan. Salah satu diantaranya menyangkut kemampuan analisa hukum islam sebagian pengelola BMT yang belum memadai,Bahkan tak jarang petugas pembiayaan akhirnya keliru menerapkan akad yang sebenarnya. Permasalahan dalam artikel ini ada dua hal yaitu fungsi Dan kegiatan Baitul Maal wat-Tamwil (BMT) dan pola dan mekanisme pengawasan terhadap Baitul Maal wat-Tamwil (BMT) berbadan hukum koperasi. Hasil dalam artikel ini menemukan bahwa fungsi dan kegiatan dalam mengoperasionalkan BMT telah dijelaskan seara rinci. Namun pola dan mekanisme pengawasan BMT berbadan hukum koperasi masih tumpang tindih antara lembaga, sehingga banyaknya nasabah yang dirugikan.
\end{abstract}

Kata kunci: Pola Pengawasan, Baitul Maal Wat Tamwil, Koperasi

\begin{abstract}
The emergence of sharia micro finance It aims to provide a better model in handling the issue of high interest rates and others in Islam. But technically operational is still faced with many problems need to be solved. One of them concerns the ability of Islamic legal analysis of some inadequate BMT managers, In fact, not infrequently financing officers finally mistakenly apply the actual contract. The problems in this article are two things: the functions and activities of Baitul Maal wat-Tamwil (BMT) and the pattern and mechanism of supervision on Baitul Maal wat-Tamwil (BMT) incorporated as cooperative law. The results in this article found that the functions and activities in operationalizing BMTs have been described in detail. But the pattern and mechanism of supervision BMT cooperative law is still overlapping between institutions, so that many customers are harmed.
\end{abstract}

Key words: System Supervision, Baitul Maal Wat Tamwil, Cooperative

\section{A. Pendahuluan}

\section{Latar Belakang}

Keuangan islam telah berkembang pesat dalam beberapa tahun terakhir; Tapi yang menjadi headline itu adalah besarnya uang yang dipindah-pindahkan mengikuti asas hukum islam. Sejak bank grameen di bangladesh dan pendirinya, Profesor Muhammad Yunus, yang merupakan hadiah perdamaian nobel pada tahun 
2016, kredit mikro dan penyimpanan mikro telah banyak dibahas sebagai instrumen pengrusakan dan pengembangan lokal. Namun keuangan mikro islam tidak termasuk dalam pengrusakan pengembangan lokal tersebut, pengumpulan tabungan kecil dan dan penyediaan pinjaman kecil berdasarkan shariah menjadi sebuah solusi (Seibel, $2007: 87$ ).

Konsep keuangan mikro syariah kemudian dikembangkan sebagai alternatif di daerah-daerah dengan populasi Muslim yang cukup besar yang mengamati larangan minat berbasis agama. Ini bertujuan untuk memberikan model yang lebih baik dalam menangani isu tersemat tingkat bunga tinggi dan lainnya. Kontrak, lembaga keuangan mikro Islam (LKMI) secara teoritis diperluas dalam bentuk barang, sebagai pengganti bantuan moneter, bantuan kepada orang yang membutuhkan sehingga mengatasi penyalahgunaan dan hutang berlebih. Keuangan mikro syariah memperluas konsep pelatihan kredit mikro dengan memasukkan amal dalam pembiayaan, dalam bentuk zakat (Sedekah) dan wakaf guna membantu satu sama lain. dan menghindari penyalahgunaan pinjaman produktif ke dalam tujuan konsumsi (Widiarto dan Emrouznejad, 2015 : 4).

Hal diatas inilah yang melatar belangi salah satu penyebab lahirnya lembaga keuangan syariah termasuk BMT. Tujuan yang ingin dicapai yaitu menampung dana umat islam yang begitu besar dan menyalurkan kembali kepada umat islam terutama pengusaha-pengusaha muslim yang membutuhkan bantuan modal untuk pengembangan bisnisnya dalam bentuk pemberian fasilitas pembiayaan kepada para nasabah berdasarkan prinsip syariah.

Baitul Maal wat-Tamwil (BMT) adalah salah satu Lembaga Keuangan Syariah yang memiliki perkembangan cukup pesat pada saat ini. Secara bahasa Baitul Maal berarti rumah usaha. Baitul Maal pada masa Nabi Muhammad dahulu berfungsi untuk mengumpulkan sekaligus menyalurkan dana sosial. Sedangkan Baitul Tamwil merupakan lembaga bisnis yang bermotif laba.(Ridwan, 2004 : 126). Dalam perkembangannya BMT juga diartikan sebagai Balai Usaha Mandiri Terpadu yang singkatannya juga BMT. Baitul Maal Wat Tamwil adalah lembaga ekonomi atau keuangan syariah non perbankan yang sifatnya informal. Disebut informal karena didirikan oleh kelompok Swadaya Masyarakat (KSM) yanng berbeda dengan lembaga keuangan perbankan dan lembaga keuangan formal lainnya (Murwati dan Sholahuddin, $2013: 301$ ).

BMT menganut prinsip syariah, semua transaksi yang dilakukan harus berprinsip syariah yakni setiap transaksi dinilai sah apabila transaksi tersebut telah terpenuhi syarat rukunnya, apabila tidak terpenuhinya maka transaksi tersebut batal. Jadi kedudukan akad sangat penting dalam penerapan prinsip-prinsip syariah dalam BMT. Namun apakah BMT konsisten dalam penerapan prinsipprinsip syariah tersebut.

Kendati demikian, implementasi prinsip prinsip syariah secara teknis operasional masih dihadapkan pada sekian banyak permasalahan perlu segera dipecahkan. Salah satu diantaranya menyangkut kemampuan analisa hukum islam sebagian pengelola BMT yang belum memadai, sehingga tak jarang dijumpai kasus seorang petugas BMT kebingungan memilih model akad syariah yang sesuai dengan kebutuhan nasabah dan rencana alokasi dana yang telah ditetapkan. Bahkan tak 
jarang petugas pembiayaan akhirnya keliru menerapkan akad yang sebenarnya. Sehingga perlu dikaji lebih mendalam.

\section{Rumusan Permasalahan}

a. Bagaimana fungsi Dan kegiatan Baitul Maal wat-Tamwil (BMT) ?

b. Bagaiaman pola dan mekanisme pengawasan terhadap Baitul Maal watTamwil (BMT) berbadan hukum koperasi ?

\section{B. Pembahasan}

\section{Fungsi dan kegiatan Baitul Maal wat-Tamwil (BMT)}

a. Fungsi dan peran Baitul Maal wat-Tamwil (BMT)

Visi Baitul Maal wat-Tamwil (BM) adalah upaya untuk mewujudkan untuk menjadi lembaga yang mampu meningkatkan kualitas ibadah para anggotanya, sehingga mampu berperan sebagai wakil Alllah di muka Bumi, memakmurkan kehidupan anggota pada khususnya dan masyarakat pada umumnya. Adapu misinya adalah membangun dan mengembangkan tatanan perekonomian dan struktur masyarakat madani yang adil berkemakmuran, berkesejahteraan, serta berkeadilan berdasarkan syariah dan ridha Allah SWT. Jadi, misi BMT ini tidak semata-mata mencari keuntungan tetapi lebih berorientasi pada pendistribusian laba yang merata adil sesuai dengan prinsip-prinsip ekonomi syariah. (Manan, 2012 : 361-362). Seperti halnya arti ayat alquran surat Al-Maidah 5:2:

"Dan tolong-menolonglah kamu dalam (mengerjakan) kebajikan dan takwa, dan jangan tolong-menolong dalam berbuat dosa dan pelanggaran. Dan bertakwalah kamu kepada Allah, sesungguhnya Allah amat berat siksa Nya.'(al-Ma'idah/5:2). (www.almanhaj.or.id/2038-antara-taawun-syari-dan hizbi.html,2007).

Ayief menyatakan bahwa lembaga keuangan mikro dengan berbagi prinsip menumbuhkan dan mengembangkan usaha mikro, untuk meningkatkan dan martabat dan membela kepentingan orang miskin. Muftiyas mengatakan secara konseptual, BMT memiliki dua fungsi: 1) baitut tamwil ("Bait" berarti rumah "attamwil" berarti barang-barang pembangunan), melakukan pengembangan usaha dan investasi produktif dalam meningkatkan kualitas ekonomi pengusaha mikro kecil, terutama dengan mendorong Kegiatan menabung dan mendukung pembiayaan kegiatan ekonomi mereka. Menurut afandi, visi BMT adalah mewujudkan lembaga profesional dan mampu meningkatkan kualitas ibadah, dan misi BMT adalah membangun dan mengembangkan tatanan ekonomi dan struktur masyarakat madani yang adil sejahtera, dan setara berdasarkan syariah. Dan diberkati oleh Allah SWT (Hasby, 2015 : 1074-1075).

\section{b. Kegiatan dan prinsip Baitul Maal wat-Tamwil (BMT)}

Sebelum mengetahui mengenai kegiatan dan prinsip BMT, perlunya kita paham status dari BMT, apakah berbadan hukum atau tidaknya. Bentuk-bentuk badan hukum BMT dapat dikelompokkan menjadi tiga kelompok yaitu Pertama, status hukum koperasi (kopontren, KSP, KSU, KBMT, KSBMT); kedua, status 
badan hukum yayasan (walaupun penggunaan status hukum yayasan bagi BMT tidak sesuai dengan buku panduan BMT yang dikeluarkan oleh pinbuk); dan ketiga, belum memiliki status badan hukum. BMT yang belum memiliki status badan hukum adalah BMT yang berbentuk kelompok swadaya masyarakat (KSM). Menurut buku panduan pusat inkubasi bisnis dan usaha kecil, BMT dapat didirikan dalam bentuk kelompok swadaya masyarakat atau koperasi (Manan, 2011 : 358).

Neni Sri Imaniyati (Imaniyati, 2010 : 102), membuat sebuah bagan mengenai bentuk-bentuk BMT yang selama ini digunakan, sebagai berikut:

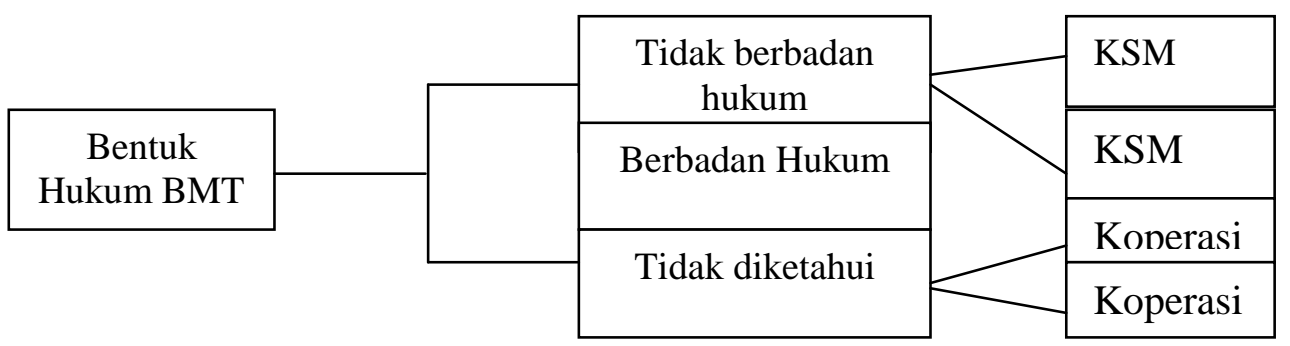

Mengenai kegiatan BMT dapat dilakukan dalam dua jenis kegiatan yaitu baitul tamwil dan baitul. Baitul tamwil mengembangkan usaha -usaha produktif dan investasi dalam meningkatkan kualitas kegiatan pengusaha kecil ke bawah dan kecil dengan mendorong kegiatan menabung dan meminjam pembiayaan ekonomi. BMT diperlukan karena masyarakat membutuhkannya sebab belum ada lembaga perbankan yang mampu berhubungan dengan pengusaha kecil bawah dan kecil (Manan, $2011: 364)$.

Dalam melaksanakan sumber dana BMT yang berasal dari anggota dan masyarakat calon anggota baik dalam bentuk simpanan maupun deposit dengan menggunakan dua prinsip yakni prinsip wadi'ah dan mudharabah. Prinsip wadi'ah yang dikembangkan yaitu wadi'ah amanah dan wadi'ah yad dhamanah. Sedangkan Prinsip mudharabah yang dikembangkan yaitu mudharabah mutlaqoh (umum/bebas) dan mudharabah muqayadah (terikat) (Ridwan, 2004 : 130-131).

Menurut Buchari Alma Donni Juni Priansa terdapat dapat juga jenis pembiayaan yang dikembangkan oleh BMT, yang semuanya mengacu pada dua jenis akad, yakni akad tijarah dan syirkah. Pada akad syirkah dibagi menjadi dua yaitu musyarakah dan mudharabah (Priansa, 2009 : 20). Sedangkan menurut Mahmud dan masjifuk zuhdi terdapat empat akad syirkah ta,awuniyah yaitu syirkah abdan, syirkah mufawadhah, syirkah wujuh, dan syirkah 'inam (Lubis dan Wajdi, 2012 : 133).

\section{Pola dan Mekanisme Pengawasan pada Baitul Maal wat-Tamwil (BMT) Berbadan Hukum Koperasi}

a. Otoritas Jasa keuangan dalam pengawasan lembaga keuangan mikro (koperasi/BMT)

Undang-undang 21 tahun 2001 tentang otoritas jasa keuangan pasal 1 ayat 1 menyebutkan otoritas jasa keuangan merupakan lembaga yang independen dan 
bebas dari campur tangan pihak lain, yang mempunyai fungsi, tugas, dan wewenang pengaturan, pengawasan, pemeriksaan, dan penyidikan. Pasal 6 huruf c UU No.21/2001 menyebutkan bahwa OJK melaksanakan tugas pengaturan dan pengawasan terhadap kegiatan jasa keuangan di sektor Perasuransian, Dana Pensiun, Lembaga Pembiayaan, dan Lembaga Jasa Keuangan Lainnya.

Terkait dengan lembaga jasa keuangan lainnya, dalam hal ini salah satunya yaitu yaitu lembaga keuangan mikro yang diatur di undang-undang No. 1 tahun 2013 tentang lembaga keuangan mikro. Pasal 28 menyatakan bahwa:

1) Pembinaan, pengaturan, dan pengawasan LKM dilakukan oleh Otoritas Jasa Keuangan.

2) Dalam melakukan pembinaan sebagaimana dimaksud pada ayat (1), Otoritas Jasa Keuangan melakukan koordinasi dengan kementerian yang menyelenggarakan urusan koperasi dan Kementerian Dalam Negeri.

3) Pembinaan dan pengawasan sebagaimana dimaksud pada ayat (1) didelegasikan kepada Pemerintah Daerah Kabupaten/Kota.

4) Dalam hal Pemerintah Daerah Kabupaten/Kota belum siap, Otoritas Jasa Keuangan dapat mendelegasikan pembinaan dan pengawasan sebagaimana dimaksud pada ayat (1) kepada pihak lain yang ditunjuk.

Sedangkan berkaitan dengan kegiatan usaha mikro berdasarkan prinsip syariah diatur dalam peraturan otoritas jasa keuangan No./POJK.05/2014 tentang penyelenggaraan usaha lembaga keuangan mikro pasal 12 menyebutkan bahwa: (1) LKM yang melakukan kegiatan usaha berdasarkan Prinsip Syariah wajib menggunakan akad yang sesuai dengan Prinsip Syariah; (2) Akad yang sesuai dengan Prinsip Syariah Kegiatan usaha penghimpunan Simpanan dilakukan dengan menggunakan Akad Wadiah, Akad Mudharabah, atau akad lain yang tidak bertentangan dengan Prinsip Syariah serta disetujui oleh OJK dan Kegiatan usaha penyaluran Pinjaman atau Pembiayaan dilakukan dengan menggunakan Akad Mudharabah, Akad Musyarakah, Akad Murabahah, atau akad lain yang tidak bertentangan dengan Prinsip Syariah serta disetujui oleh OJK.

Dapat dilihat bahwa pola dan mekanisme yang dilakukan otoritas jasa keuangan pada lembaga keuangan mikro sangat lemah karena fungsi pengawasan sebatas koordinasi, dan berkenaan dengan kegiatan usaha yang berdasarkan prinsip pun demikian. Sehingga banyak kelemahan yang muncul dalam pengawasan tersebut, diantaranya: Pertama, terkait pengertian pelaku jasa keuangan tidak mencakup lembaga keuangan mikro baik yang melaksanakan kegiatan secara konvensional maupun secara syariah. Kedua, terkait syarat-syarat pemberian fasilitas penyelesain pengaduan konsumen oleh Otoritas Jasa Keuangan tidak memungkinkan bagi lembaga keuangan mikro yang kegiatan usahanya dalam lingkup kecil (mikro). Ketiga, tidak ditentukannya ruang lingkup kerugian finansial yang dialami oleh nasabah penyimpan terkait hak-hak nasabah penyimpan yang mendapat perlindungan (Ma’wa, 4).

\section{b. Pengawasan Dewan Pengawas Syariah Terhadap Baitul Maal wat- Tamwil (BMT)}

Dewan pengawas syariah adalah lembaga yang ditunjuk oleh Majelis ulama indonesia melalui dewan syariah nasional untuk melaksanakan fatwa yang 
dikeluarkan oleh DSN-MUI (www.dsnmui.or.id/index.php?page=sekilas). Dewan pengawasan syariah merupakan tolak ukur penting dari sebuah lembaga keuangan syariah dari sebuah lembaga keuangan syariah dalam rangka menjalankan prinsipprinsip syariat islam. Dalam keputusan DSN-MUI Nomor 3 Tahun 2000, terdapat pengaturan mengenai dewan pengawas syariah terhadap lembaga keuangan syariah diantaranya, tugas dan fungsi Dewan pengawasan syariah adalah:

1) Tugas utama DPS adalah mengawasi kegiatan usaha lembaga keuangan syariah agar sesuai dengan ketentuan dan prinsip syariah yang telah difatwakan oleh DSN

2) Fungsi utama DPS adalah:

a) Sebagai penasehat dan pemberi saran kepada direksi, pimpinan unit usaha syariah dan pimpinan kantor cabang syariah mengenai hal yang terkait dengan aspek syariah

b) Sebagai mediator antara lembaga keuangan syariah dengan DSN dalam mengkomunikasikan usul dan saran pengembangan produk dan jasa dari lembaga keuangan syariah yang memerlukan kajian dan fatwa dari DSN (Aziz, Hisyam dkk, $2015: 25$ ).

Jenis pengawasan yang dilakukan DPS oleh Irawan D.Soedrajat ada 3 jenis yaitu:

1) Preventif/Pencegahan (Riqabah Musbaqah); pada saat pre audit DPS mengecek peraturan dan SOP, rencana kerja, dan opini syariah

2) Memastikan (Riqabah Lahiqah) : pada saat post audit DPS memastikan akad, produk, dan SOP

3) Operasional (Riqabah A'mal) : pada saat operational controlling DPR melakukan pemeriksaan dan evaluasi.

\section{c. Pengawasan oleh Kementrian koperasi dan UKM Terhadap BMT berbasis koperasi}

Pengawasan yang dilakukan oleh Kementrian Koperasi dikarenakan BMT Amratani berbadan hukum koperasi. Sebagaiaman telah dijelaskan bahwa BMT yang berbadan hukum koperasi dalam bentuk Koperasi Jasa Keuangan Syariah dan tunduk pada Undang-Undang No. 25 Tahun 1992 tentang Perkoperasian. Sedangkan mengenai pengawasan koperasi diatur dalam peraturan mentri koperasi dan usaha kecil dan menengah Nomor 39/Per/M.KUKM/XII/2007 Tentang pedoman pengawasan koperasi jasa keuangan syariah dan unit jasa keuangan syariah koperasi. Pasal 1 ayat 1 menjelaskan bahwa pengawasan adalah kegiatan pembinaan, pemantauan, pemeriksaan, dan penilaian kesehatan Koperasi Jasa Keuangan Syariah dan Unit Jasa Keuangan Syariah Koperasi oleh pemerintah dalam hal ini Menteri di tingkat pusat dan pejabat yang diberi wewenang menjalankan tugas pembantuan di tingkat daerah dengan tujuan agar pengelolaan Koperasi Jasa Keuangan Syariah dan Unit Jasa Keuangan Syariah Koperasi dilakukan secara baik dan terkendali sehingga menumbuhkan kepercayaan dari pihak terkait.

Pasal 17 menyebutkan bahwa Menteri mengangkat Pejabat Pengawas yang berperan sebagai pengawas Koperasi Jasa Keuangan Syariah dan Unit Jasa Keuangan Syariah Koperasi. Pejabat pengawas mempunyai wewenang : 
1) Menerima laporan mengenai kondisi organisasi, usaha dan permodalan Koperasi Jasa Keuangan Syariah dan atau Unit Jasa Keuangan Syariah;

2) Melakukan audit atau meminta auditor independen untuk melakukan audit terhadap semua dana, surat-surat berharga, pembukuan, kertas kerja, catatan dan semua sumber informasi yang dikuasainya serta laporan pemeriksaan oleh pengawas yang akan diberikan kepada pengurus Koperasi Jasa Keuangan Syariah dan atau Unit Jasa Keuangan Syariah Koperasi;

3) Merekomendasikan kepada Menteri untuk menghentikan kegiatan usaha dan atau mencabut izin usaha Jasa Keuangan Syariah apabila terdapat dugaan kuat berdasarkan bukti-bukti nyata yang ditemukan bahwa Koperasi Jasa Keuangan Syariah dan atau Unit Jasa Keuangan Syariah:

a) menjalankan usaha keuangan yang tidak sehat dan tidak aman;

b) melanggar ketentuan hukum dan peraturan perundang-undangan yang berlaku; atau

4) Mengeluarkan perintah untuk menempatkan Koperasi Jasa Keuangan Syariah dan atau Unit Jasa Keuangan Syariah dalam pengawasan administratif.

Pejabat berwenang membubarkan Koperasi Jasa Keuangan Syariah atau koperasi yang mempunyai Unit Jasa Keuangan Syariah jika Koperasi yang bersangkutan, berdasarkan penilaian Dewan Pengawas Syariah telah terbukti melanggar prinsip-prinsip syariah dalam melaksanakan kegiatan usahanya. Berdasarkan aturan tersebut, dengan wewenang yang ada, semestinya Kementrian/Dinas Koperasi juga berkepentingan untuk mewujudkan optimalisasi DPS di KJKS yang ada dalam koordinasinya (www.indonesiaoptimis.com, 2011).

Pengawasan BMT yang berbadan hukum koperasi dilakukan oleh Kementrian Koperasi dan UKM di mana domisili BMT berada, apabila di tingkat kota dilakukan oleh Dinas Koperasi dan UKM Kota/Kabupaten, sedangkan bila di tingkat provinsi, maka dilakukan oleh Dinas Koperasi dan UKM Provinsi (Masyithoh, 2014 : 28-29).

Namun kenyataan di lapangan menunjukkan, Dinas Koperasi selama ini sudah cukup sibuk dengan mengurusi koperasi-koperasi yang tidak sehat secara modal dan keuangan, belum menyentuh koperasi yang tidak sehat secara kepatuhan syariah. Seperti pada kasus yang terjadi di bantul dilakukan oleh Koperasi BMT Amratani, di mana dinas koperasi setempat tidak mengambil tindakan terhadap Koperasi yang dalam menjalankan kegiatan usaha dengan tidak berlandaskan prinsip-prinsip syariah. Padahal setiap dinas koperasi telah membentuk pejabat pengawas yang khusus mengawasi lembga mikro terutama BMT. Hal ini yang menyebabkan mekanisme pengawasan pada koperasi BMT menjadi lemah, karena minimnya usaha dari dinas koperasi.

Maka jika dibuat sebuah gambaran bagan mengenai bentuk-bentuk pengawasan dari ketiga lembaga diatas terhadap BMT berbadan hukum Koperasi yaitu sebagai berikut : 


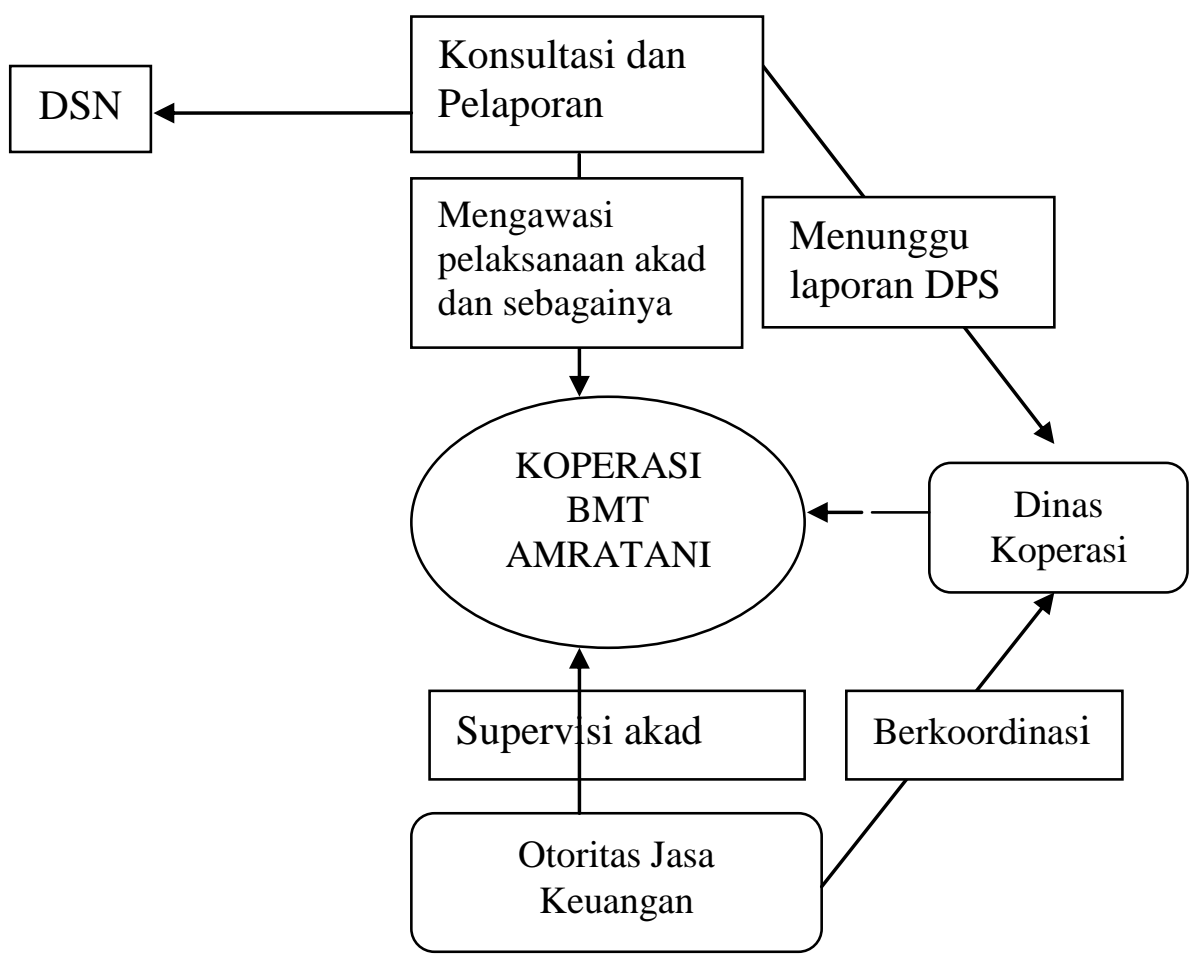

Jika dilihat dari bentuk bagan diatas maka pola pengawasan yang selama ini dilakukan perlu adanya sinkronisasi penindakan ketika Koperasi BMT terjadi masalah, agar tidak mengulangi permasalahan yang sama.

\section{Simpulan}

a. Berdasarkan penjelasan pada rumusan masalah pertama dapat disimpulkan bahwa fungsi Baitul Maal Wat Tamwil (BMT) memiliki tujuan yang sangat manusiawi yaitu tolong menolong sesama manusia terutama kepada masyarakat yang lebih membutuhkan. Adanya BMT ini juga membuat masyarakat dapat menabung keuanganya menurut syariat islam. Prinsip prinsip syariah yang digunakan juga sangat adil yang menggunakan prinsip wadi'ah dan mudharabah Dan dua jenis akad pembiayaan, yakni akad tijarah dan syirkah.

b. Model pengawasan BMT yang cukup lemah dan berbelit-belit. Pertama, peran pengwasan otoritas jasa keuangan terhadap BMT hanya sebatas supervise akad, sedangkan untuk penindakan harus berkoordinasi dengan dinas koperasi. kedua, peran pengawasan dewan pengawas syariah sebenarnya diberikan ruang yang cukup maksimal akan tetapi masih saja terjadi masalah, pola seperti ini disebabkan tidak adanya koordinasi antara direksi dan DPS. Dan ketiga, peran pengawasan kementrian koperasi dan UKM yang mana hal ini diwakili oleh dinas koperasi tidak dapat bertindak 
lebih, jika tidak laporan dari dewan pengawas syariah, sehingga peran dinas koperasi hanya bersifat pasif.

\section{Daftar Pustaka}

Abbas Arfan, kaidah-kaidah fiqh muamalah dan aplikasinya dalam ekonomi islam dan perbankan syariah,Jakarta,Direktorat Pendidikan Tinggi Islam Direktorat Jenderal Pendidkan Islam Kementrian Agama RI, 2012

Abdul Manan, Hukum Ekonomi Syariah Dalam Perspektif Kewenangan Peradilan Agama, Jakarta, Kencana Prenadamedia Group,2012

Buchari Alma Donni Juni Priansa, Manajemen Bisnis Syariah,cetakan 1, Bandung, Alafabeta, 2009

Muhammad Ridwan, Manajemen Baitul Maal Wa Tamwil (BMT) ,Yogyakarta, UII Perss, 2004

Neni Sri Imaniyati, Aspek-aspek Hukum BMT (Baitul Maal Wal Tamwil), Bandung, PT. Citra Aditya Bakti,2010

Suhrawardi K. Lubis, Farid Wajdi, Hukum Ekonomi Islam, Jakarta,Sinargrafika,2012

\section{Jurnal dan Artikel}

Abdul Aziz, Hisyam, Dkk, Peran Dewan Pengawas Syariah Dalam Operasional Baitul Maal Wat Tamwil (Studi Di BMT Alfa Dina Karanganyar), Volume III No.II, Oktober 2015,

Hans Dieter Seibel, Islamic microfinance in Indonesia: the challenge of institusional diversity, regulation, and supervision, jurnal of social issue in southeast Asia Vol. 23, No. 1

Hariandy Hasby, Islamic Microfinance Institution: The Capital Structure, Growth, Performance And Value of firm In Indonesia, Procedia - Social and behavior sciences 211 (2015) 1073-1080

Indra Widiarto, Ali Emrouznejad, Social and Financial Efficiency of Islamic microfinance: A data Development Analysis Aplication

Kaffi Wanatul Ma'wa, Perlindungan Hukum Bagi Nasabah Penyimpan Lembaga Keuangan Mikro Syariah Yang Mengalami Kerugian Finansial, Fakultas Hukum Brawijaya 
Novita Dewi Masyithoh, Analisis Normatif Undang-Undang No. 1 Tahun 2013 Tentang Lembaga Keuangan Mikro (LKM) Atas Status Badan Hukum Dan Pengawasan Baitul Maal Wat Tamwil (BMT), Volume V/edisi 2/Oktober 2014

Sri Murwati dan Muhammad Sholahuddin, peran keuangan lembaga mikro syariah untuk usaha mikro di wonogiri, Jurnal Fakultas Ekonomi Universitas Muhammaddiyah Surakarta

\section{Peraturan - Peraturan}

Direktorat Putusan Mahkamah Agung Republik Indonesia, Putusan No Nomor 410 $\mathrm{K} / \mathrm{Ag} / 2014$, Putusan.mahkamahagung.go.id

Pusat Pengkajian Hukum Islam Dan Masyarakat Madani, Kompilasi Hukum Ekonomi Syariah, Edisi Revisi, Jakarta,Prenada Mediagroup,2009

Peraturan otoritas jasa keuangan No./POJK.05/2014 tentang penyelenggaraan usaha lembaga keuangan mikro

Peraturan mentri koperasi dan usaha kecil dan menengah Nomor 39/Per/M.KUKM/XII/2007 Tentang pedoman pengawasan koperasi jasa keuangan syariah dan unit jasa keuangan syariah koperasi

Undang - undang Nomor 21 Tahun 2001 Tentang Otoritas Jasa Keungan undang No. 1 tahun 2013 tentang lembaga keuangan mikro

\section{Website}

www.almanhaj.or.id/2038-antara-taawun-syari-dan-hizbi.html. diakses tangggal 6 Mei 2016

www.dsnmui.or.id/index.php?page=sekilas, diakses tanggal 7 Mei 2017

www.indonesiaoptimis.com/2011/10/optimalisasi-pengawasan-syariah-di-bmt.html, diakses tanggal 7 Mei 2017 